\title{
ひずみ分布検出のための活性エラストマーの電特特牲評西
}

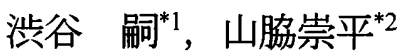

\section{Electrical Property of Conductive Elastomers for Sensing Strain Distribution}

\author{
Yotsugi SHIBUYA*3 and Shuhei YAMAWAKI \\ *3 Akita Universiry, Dept. of Mechanical Engineering \\ 1-1, Tegata Gakuen-machi, Akita, 010-8502 Japan
}

\begin{abstract}
A conductive elastomer is applied to detect damage in GFRP laminating with a hole. As the electrical resistance changes due to deformation of the material, strain distribution in the composite structure is measured using the conductive elastomer. It is an advantage to apply sensing in wide area along the conductive network. Possibility of the damage detection is demonstrated in comparison with measured strain distributions using the method.
\end{abstract}

Key Words : Conductive Elastomer, Electric Resistance, Strain Sensor, Damage Detection

\section{1. 精}

複合材料は軽量で機械的特性に優れている特徴 から，航空宇宙分野において主要な構造材料とし て利用が拡大している。しかし, 異方性の性質か ら界面はく離や層内き裂などの複雑な損傷形態を 示す。破壊を未然に防ぐために, 構造中の損傷の 有無を常時評価するへルスモニタリングが重要と なっている。損傷の検出手法として材料の電気抵 抗計測が応用されてきている ${ }^{(1)-(3)}$ 。

本研究では, 円孔を有する GFRP 積層板に導電性 エラストマーを配置し, 損傷検出にためのセンサ として利用することについて検討する。導電エラ ストマーは，変形によって電気抵抗が変化するの で, 電気抵抗を計測することでひずみを検出する。 この方法は，導電エラストマーで積層板の内部に 電気回路を形成することで電気回路内においてひ ずみの分布を広い範囲で計測できる。円孔から離 れた試料の平行部分のひずみと円孔周りのひずみ 分布の比較から，応力集中によって生じる円孔周 りの損傷の発生について検討する。

\footnotetext{
${ }^{* 1}$ 正員, 秋田大学（宁010-8502 秋田市手形学園町 1-1）

*2 秋田大学

E-mail: yshibuya@gipc.akita-u.ac.jp
}

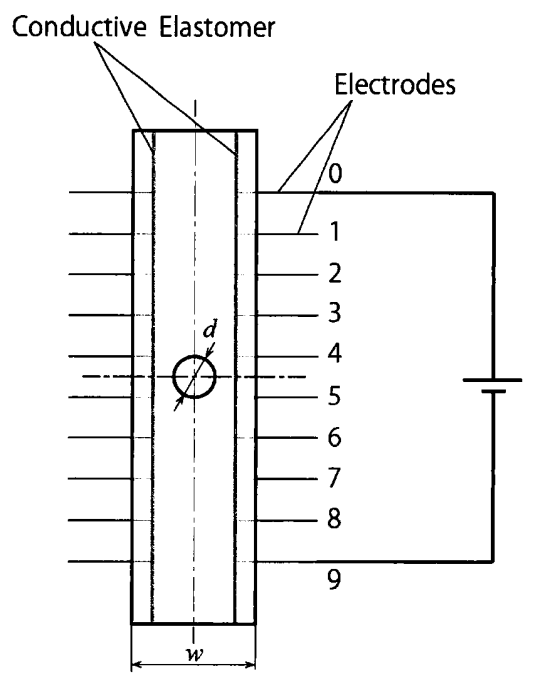

Fig.1 Specimen and strain measurement configuration.

\section{2. 实験方法}

導電性エラストマーをセンサとして利用した損 傷検出手法について検討するために, 図 1 に示す 内部に電気回路を有する試料を用いて引張試験に おける導電性エラストマーの抵抗変化を調査した。 Glass/Epoxy の GFRP を基板とし, 試料の長手方向 に 2 本の導電性エラストマーを配置した GFPP の サンドイッチ構造を作製した。また, 引張試験時 
の導電性エラストマーの抵抗を計測するために番 号 0 から 9 の電極端子を設置し, 端子 0 と 9 の間 に一定の電流を加え, 端子 1 から 8 は抵抗測定の ための電位を検出した。

試料の寸法は幅 $w$ が $15 \mathrm{~mm}$, 線状導電性エラス トマーを GFRP 板でサンドイッチした試料全体の 厚さは $2 \mathrm{~mm}$, 試料中央の円孔の直径 $d$ は $5 \mathrm{~mm}$ であ る。試料はそれぞれ 10 個の電極端子を有する 2 本 の線状導電性エラストマー（断面 $0.5 \mathrm{~mm} \times 0.5$ $\mathrm{mm}$ ) が Glass/Epoxy の GFRP でサンドイッチされ ている。電極の間隔は等間隔に $5 \mathrm{~mm}$ としている。 試料中央部に円孔を配置し, 引張試験において応 力集中によりひずみ分布が変化するように設定し ている。また，実際のひずみ計測のために，試料 の平行部と円孔部の 2 箇所にひずみゲージを貼り 付け, 引張試験中の実際のひずみも同時に測定す る。

\section{3. 結果と孝寮}

損傷検出手法について検討するために，図 1 に示し た試料に引張荷重を適用し，最終破断にいたるまでの 付加と導電性エラストマーの電極間の電気抵抗変化を 計測した。

図 2 は試料が最終破断にいたるまでの電極端子 $2-$ 3 (試料平行部) と電極端子 4-5 (円孔部) のひず みゲージにより測定されたひずみと電極間の導電性エ ラストマーの抵抗変化率を示したものである。試料の 破断は円孔周りの応力集中によって, 電極 $4-5$ 間に 生じる。この部分のひずみは平行部よりおおよそ 2 倍 の大きさになっている。

電極間の抵抗変化率 $\Delta R / R_{0}$ は変形前の電極間抵抗 $R_{0}$ からの抵抗変化 $\Delta R$ と変形前の抵抗との比として 定義されている。図中において黒い線は試料の平行部 に相当する電極端子 $2-3$ 間の抵抗変化率を示してい る。電極端子 $2-3$ 間においては，最終破断までほぼ 線形的に変化していることがわかる。一方，赤の実線 で示した電極端子 $4-5$ 間の抵抗変化率はひずみが 0.013 付近までは平行部と同様に線形的に変化するが, その後, 変化が大きくなり, 最終破断直前で急激に上 昇し，最終破断にいたっている。これは，内部に生じ た損傷によって，局所的なひずみの増加によって，抵 抗変化率が大きく変動したものと推察できる。平行部 の抵抗変化率と円孔部の抵抗変化率を比較することに よって，円孔部の抵抗の異常な変化を検出し，損傷の 発生を検出することを期待できる。
次に，各電極間領域における，導電性エラストマー のゲージ率について検討した。ゲージ率 $K$ は次式のよ うに定義することができる。

$$
K=\frac{\Delta R / R_{0}}{\varepsilon}
$$

図2からゲージ率はグラフの曲線の傾きとして算出す ることができ，微小ひずみ領域のゲージ率はおよそ 7.9 である。ひずみが大きくなるにつれて，このゲー ジ率は大きくなる傾向がある。

\section{4. 結 言}

円孔を有する GFRP 積層板の損傷検出を目的と して導電性エラストマーをセンサとして，導電性 エラストマーのひずみ分布計測を行った。試料平 行部の抵抗率の変化と円孔周辺の応力集中部の抵 抗変化率を比較することによって，損傷の発生の 検出の可能性について示した。

\section{文献}

(1) Jie Wen, Zhenhai Xia, Fred Choy, "Damage detection of carbon fiber reinforced polymer composites via electrical resistance measurement," Composites: Part B, Vol.42 (2011), pp.77-86.

(2) M. Nofar, S.V. Hoa, M.D. Pugh, "Failure detection and monitoring in polymer matrix composites subjected to static and dynamic loads using carbon nanotube networks," Composites Science and Technology, Vol.69 (2009), pp.1599-1606.

(3) T.H. Swait, F.R. Jones, S.A. Hayes, "A practical structural health monitoring system for carbon fiber reinforced composite based on electrical resistance", Composites Science and Technology, Vol.72 (2012), pp.1515-1523.

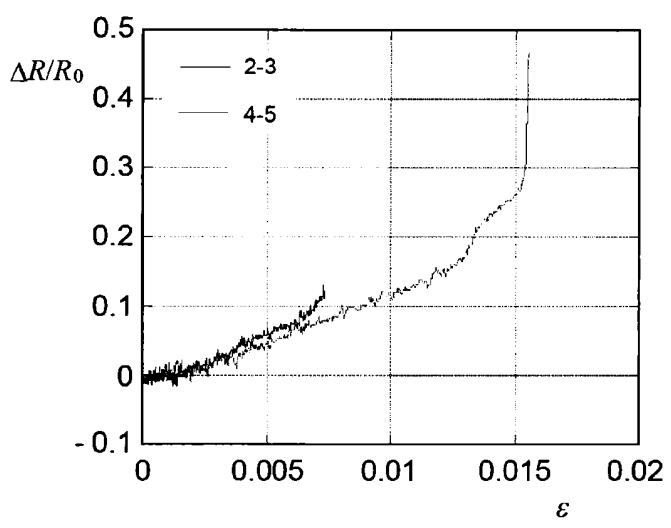

Fig.2 Variation of specific electrical resistance between electrodes. 